\title{
Žánrové specifikum deníkových zápisků věnovaných dětem a jedno česko-slovenské srovnání
}

\author{
Lenka Odehnalová (Brno)
}

\begin{abstract}
Abstrakt
Současná literatura je bohatá na vznik autobiografických žánrů: memoárů, esejů a samožejmě deníků rưzného typu a zaměření. Ve slovanských literaturách se v posledních letech objevují deníkové záznamy autorek, jež jsou věnovány dětem, jejich výchově, dospívání apod. Příspěvek je zaměřen na žánrové specifikum deníkových záznamů o dětech vznikajících v současné české literatuře, konkrétně v tvorbě žurnalistky Lucie Nachtigallové (roč. 1977). Cílem príspěvku je poukázat na žánrový posun Deníku fejsbukové matky ve vztahu ke klasickému přikladu deníků věnovaných dětem z pera slovenské spisovatelky Eleny Maróthy-Šoltésové (1855-1939) Moje deti.
\end{abstract}

\section{Klíčová slova}

slovanské literatury; ženské autorky; literární žánr; deníkové záznamy; Lucie Nachtigallová; komparativní metoda; žánrový posun

\section{Abstract \\ Genre Specific Features of Diary Records Dedicated to Children and One Czech-Slovak Comparison}

Contemporary literature is rich in the emergence of autobiographical genres: memoirs, essays and, of course, diaries of different types and orientations. In recent years, the Slavonic literatures include diary records of female authors dedicated to children, their upbringing, adolescence and other features. The paper focuses on genre specific features of diary records on children that emerge in contemporary Czech literature, namely in the work of the female journalist Lucie Nachtigallová (born in 1977). The aim of the paper is to show a genre shift of The Facebook Mother's Diaries [Deníky fejsbukové matky] in relation to a classic example of diaries dedicated to children written by the Slovak female writer Elena Maróthy-Šoltésová (1855-1939) My Children [Moje deti].

\section{Key words}

Slavonic literatures; female authors; literary genre; diary records; Lucie Nachtigallová; comparative method; genre shift

Studie vznikla za podpory Specifického výzkumu Filozofické fakulty Masarykovy univerzity Ztracení na hraně staletí: Mladí lidé v současných prózách postkomunistického prostoru MUNI/A/1360/2020. 
Současnost s sebou přináší vznik deníků a deníkových záznamů různého typu a charakteru, jakož i autorského původu. Ve slovanských literaturách vznikají deníkové záznamy, jejichž autoři jsou nejen spisovatelé, ale také hudebníci, zpěváci, herci, politici, sportovci aj. Tento jev lze interpretovat slovy ruského literárního vědce Andreje Bursova tak, že významné osobnosti cítí svůj význam, a proto se o sobě snaží zanechat hmatatelnou památku, která by jejich život připomínala dalším generacím. ${ }^{1}$

Zvláštní místo mezi vznikajícími deníky zaujímají zejména ty, které jsou věnovány dětem: jejich ranému dětství, školní docházce, nebo dospívání. Tento typ deníků se stal v posledních letech neoddělitelnou součástí „ženské“ literatury a vzhledem k jeho úzkému propojení s rodinou tento typ deníku označíme jako rodinný. ${ }^{2}$ Najdeme ho v tvorbě polské autorky Małgorzaty Mroczkowské (Dziennik przetrwania. Zapiski niedoskonałej matki, 2018), ruské spisovatelky Maši Traub (Дневник мамъ первоклассника, 2012) i slovenské spisovatelky Dany Hlavaté (Dennik chaotickej matky, 2021). Když pohlédneme na současnou českou literaturu, příklad deníků rodinného typu nacházíme v tvorbě mladé žurnalistky Lucie Nachtigallové (roč. 1977)³. Celkově tři díly deníkových záznamů, jež autorka pojmenovala Deniky fejsbukové matky (2016-2018), jsou psány formou statusů publikovaných na sociální síti Facebook. ${ }^{4}$ Cílem př́íspěvku bude poukázat na žánrový posun Deniků fejsbukové matky, jež je patrný ve vztahu k deníkovým zápiskům slovenské realistické spisovatelky Eleny Maróthy-Šoltésové (1855-1939).

Z hlediska žánru se jedná o deník, jenž se skládá, jak bylo uvedeno výše, ze statusů uveřejněných na sociální síti Facebook. Forma deníku Lucie Nachtigallové odpovídá současnému životnímu stylu dnešní doby. ${ }^{5}$ Délka statusů závisí na tématu, kratší statusy mají podobu věty, delší jsou v délce odstavce. Nejdelší statusy jsou zaměřeny zejména na děti. Žánrem deníku psaného formou statusů si Lucie Nachtigallová získává širší okruh čtenářů, zejména dnešní mladou „počítačovou generaci“. Statusy se vyznačují krátkostí a výstižností, jsou řazeny chronologicky (juxtapozičnost), na první pohled na sebe nenavazují, avšak pozorujeme jejich vnitřní propojenost tím, že se autorka k některým tématům vrací. Dominantou se stává příběhovost, každodennost, nenáročnost. Autorka deníků Lucie Nachtigallová je matkou tří dětí - dvojčat Viktorie a Františka a nejmladší dcery Alžběty.

1 BURSOV, Boris: Dostojevskij a jeho svět. Praha: Odeon, 1978, s. 11.

2 V dané souvislosti např́klad Hana Bočková vymezuje z formálně obsahového hlediska čtyři typy deníku: cestovní deník, deník básnický, pracovní a literární zápisník (BOČKOVÁ, Hana: K problematice deniku jako literárniho žánru. In: Sbornik prací Filozofické fakulty brněnské univerzity. 1989-1990. D 36-37, s. 43-44).

3 Lucie Nachtigallová je absolventkou Fakulty sociálních věd UK, v minulosti působila ve Velké Británii, Itálii a Španělsku jako novinářka. Kromě Deníku fejsbukové matky (2016-2018), díky kterým se etablovala jako spisovatelka, napsala ještě turistického průvodce pro děti Výlety s tajenkou (2018). Blíže viz https:// www.velkadobrodruzstvi.cz/m/o-nas.php.

4 První díl Deniku fejsbukové matky autorka napsala již v roce 2016, stal se mezi čtenáři natolik populární, že autorka napsala jeho další dvě pokračování - Deník fejsbukové matky pokračuje (2017) a Deník fejsbukové matky (ne)konči (2018).

5 V roce 2014 používalo v České republice sociální sít Facebook až 4,4 mil. lidí, což představovalo přibližně $40 \%$ obyvatel (POSPÍŠILOVÁ, Marie: Facebooková (ne)závislost. Praha: Univerzita Karlova, 2016, s. 12). 
První díl Deniku fejsbukové matky je opatřen dedikací autorčině mamince. ${ }^{6}$ Začíná rokem 2009, v němž se autorka s Facebookem teprve seznamuje. První status autorky zní následovně: „Ahoj, objevila jsem facebook. Nevim, zdali budu stíhat sem něco psát, ale aspoň si počtu, jak se máte a co děláte. Prosím vás, co znamenaji ty kostičky a pand’uláčci dole?"7 Další statusy zachycují, jak autorka postupem času objevuje možnosti Facebooku, např́íklad kontakt $\mathrm{s}$ širším okruhem přátel nebo vkládání fotografií. ${ }^{8}$ Periodicita statusů závisí na situaci, někdy autorka status uvádí každý den, jindy se objevuje jeden až dva statusy v týdnu. $\mathrm{V}$ některých případech jsou statusy doplněny vtipnou fotografií. Například ke statusu: „Vážně zvažuji otevřeni domácí soukromé školky u Nachtigallů. tři naše děti ostatním připadaji zřjejě jako nedostatečný počet. Dnes přes noc hlídáme navic Pát’u od sousedi̊, zítra a pozitř́ Kubika od kamarádky [...] “9 je připojena fotografie devíti párů dětských botiček. V ročních intervalech se objevují bilanční statusy.

Lze říci, že formální charakter deníkových zápisků, tj. jejich napsání formou facebookových statusů rovněž působí na tematickou heterogenitu textu. Témata, jež se na stránkách Deniku fejsbukové matky objevují, reflektují především autorčin osobní život. Můžeme je rozdělit do tří okruhů: 1. téma dětí, 2. témata spjatá s ostatními členy rodiny, 3. objektivní realita. První okruh a největší plochu zaujímá téma dětí, v němž můžeme vymezit subtémata zahrnující důležité momenty v životě dětí (narozeniny, svátky, první den ve školce), svátky (Vánoce, Velikonoce) a společné aktivity (malování, vaření, pečení cukroví, barvení velikonočních vajíček aj.), častým subtématem jsou rovněž nemoci dětí (angíny, chřipky aj.) ${ }^{10}$. Téma dětí je v deníku dominujícím tématem. Druhý okruh představují témata spjatá s ostatními členy rodiny, jimiž jsou matka (autorka samotná), otec, babička a fenka Róza. Čteme např́klad o průběhu vážné nemoci a uzdravení autorčiny kamarádky, o smrti spolužáka, o narozeninách autorky, což s sebou na Facebooku přináší i falešnou iluzi zájmu ze strany přátel. Autorka píše také o beletrii, kterou sama nebo společně s manželem přečetla. ${ }^{11}$

Poslední okruh témat vytváří objektivní realita, události let 2009 až 2011. Ukotvenost v uvedené době dokumentují politické, společenské, sportovní a kulturní události, o nichž se autorka na stránkách deníku zmiňuje. Objevují se například vzpomínky na významné osobnosti, například na herečku Milenu Dvorskou, na zpěváka Petra Muka nebo Michaela Jacksona. Autorka komentuje informace o zásnubách Williama a Kate, později o jejich královské svatbě ve Velké Británii. Dále autorka reaguje na zprávy o atentátu v moskevském metru, o letecké katastrofě ve Smolensku a v Jaroslavli, o výbuchu islandské sopky, který

6 „Tuto knižku věnuji s velkou láskou, obdivem a úctou nejlaskavějši babičce a prababičce pod sluncem - Marjánce z Klimkovic." NACHTIGALLOVÁ, Lucie: Denik fejsbukové matky. Praha: Dobrovský s.r.o., 2016, s. 6.

7 Tamtéž, s. 7 .

8 „Super! Dokázala jsem ke statusu přidat fotku. Trualo mi to 3 hodiny, ale konečně mám fotku na Timeline. Tak to jsme my - zleva Fanda, Alžběta a Viktorka." Tamtéž, s. 7.

9 Tamtéž, s. 84.

10 „Trčime doma. Všechny děti mají to samé (jako ostatně celý zbytek republiky) - nudle, kašel a teploty. Zatímco holky trpèlivě stavi zoologickou zahradu z kostiček, komunikuji, pomáhaji a jsou v rámci možností milé, tak synáček řve, kňourá a umírá... Chlap!“ Tamtéž, s. 106.

11 Tamtéž, s. 100. 
ochromil leteckou dopravu nebo o smrti prezidenta Václava Havla. Ze sportovních událostí autorka poukazuje na úspěchy českých sportovců - Barbory Špotákové a Petry Kvitové. Jak můžeme vidět, první dva okruhy témat mají subjektivní charakter, poslední okruh témat můžeme nazvat objektivním; je v něm však pořád přítomno hodnocení autorky.

Abychom poukázali na žánrový posun deníkových zápisků rodinného typu, deníkové zápisky Lucie Nachtigallové srovnáme s klasickým příkladem deníků věnovaných dětem, a to s deníkovými zápisky Eleny Maróthy-Šoltésové (1855-1939) ${ }^{12}$, slovenské spisovatelky, představitelky tzv. první vlny realismu ${ }^{13}$ a zároveň vůdčí osobnosti ženského hnutí přelomu 19. a 20. století. Šoltésová do slovenské literatury vstoupila v roce 1881 povídkou $\mathrm{Na}$ dedine. Zejména v prozaické tvorbě osmdesátých až devadesátých let 19. století autorka rozvinula koncepci tzv. ideálního realismu, od níž se v autobiografické próze odklonila. ${ }^{14}$ Chtěli bychom zdůraznit, že o rozvíjení autobiografických žánrů ve slovenské literatuře druhé poloviny 19. století se značnou mírou přičinily zejména ženské autorky: Šoltésová svými deníkovými zápisky Moje deti (1923-1924, chorv. 1925, franc. 1928-1929, čes. 1957) a memoáry Sedemdesiat rokov života (1925); Božena Slančíková Timrava autobiografickými novelami Skúsenost’ (1902) a Všetko za národ (1926). Připomeňme také Terézii Vansovou, která sestavila biografii svého muže Ján Vansa (1938, původně však pod názvem Môj muž, v periodiku Slovenské pohlady 1926-1928) a rodičů Terézia Medvecká, rodená Lange (1900).

Dílo Moje deti $i^{15}$ představuje pro slovenskou literaturu trvalou hodnotu, shodují se v tom badatelé v různých obdobích (J. K. Garaj, A. Mráz, J. Čečetka, M. Mináriková,

12 Zkoumání osobnosti a tvorby Eleny Maróthy-Šoltésové se v minulosti věnovali např́íklad A. Štarková, J. K. Garaj, I. Kusý, Ž. Handzová, M. Mináriková a další. Medailónek o jejím životě a tvorbě napsali J. K. Garaj a A. Štarková, význam autorky pro slovenskou literaturu zhodnotil I. Kusý, v roce 1989 se objevuje první monografie o Šoltésové - z pera Ž. Handzové. K hlubšímu poznání autorčiny tvůrčí osobnosti přispělo i souborné vydání korespondence s Boženou Slančíkovou Timravou. První a zatím jediná konference věnována osobnosti a tvorbě E. M. Šoltésové byla uspořádána v roce 1985 ve městě Zvolen. Ze souboru studií z uvedené konference pocházejí také studie o deníkových zápiscích Moje deti: v kontextu biografie autorky (Handzová), z hlediska textologicko-stylistického (Mináriková) nebo z tematického hlediska (Baginová).

13 Představitelé tzv. první vlny slovenského realismu vstupují do literatury v sedmdesátých a osmdesátých letech 19. století. K nejvýznamnějším patří P. O. Hviezdoslav, S. H. Vajanský, K. Banšell, E. M. Šoltésová, T. Vansová, M. Kukučín a další. Nutno zdůraznit, že jde vůbec o první období slovenské literatury, kdy se do popředí dostávají ženské spisovatelky, jejichž díla jsou schopna konkurovat spisovatelům-mužům. Na tento fakt poukazuje také Andrej Mráz: „Ženy v našej literatúre, ktorých tvorbu možno priradit’ $k$ prácam mužských, zjavily sa až v epoche realistickej." (MRÁZ, Andrej: Dejiny slovenskej literatúry. Bratislava: Slovenská akadémia vied a umení, 1948, s. 228)

14 Díla, např́ílad povídka Na dedine (1881), novela V čiernickej škole (1891) nebo román Proti prúdu (1894), měla realistický základ, Šoltésová využívala idealizaci postav s účelem mravního zušlechtění čtenáře. V dopise B. S. Timravě z 19. 12. 1931 autorka vysvětluje, proč se později od idealizace odklání: „[...] moja beletria stála vždy na slabých nohách, zabrdnutá do idealizmu, ktorý żivot neospravedlňuje, teda odchylujúca sa od životnej pravdy, nuž sa už nechytám do nej. "ROSENBAUM, Karol - KUSÝ, Ivan (eds.): Korešpondencia Timravy a Šoltésovej. Bratislava: Slovenská akadémia vied a umení, 1952, s. 195.

15 Deníkovým zápiskům Eleny Maróthy-Šoltésové Moje deti ve vztahu k Dostojevského Deniku spisovatele jsme se zabývali ve studii „Knihy majú svoje osudy už ked" sa tvoria..." Denikové zápisky Moje deti E. M. Šoltésové a Dostojevského Denik spisovatele. Blí̌ze viz PAUČOVÁ, Lenka: „Knihy majú svoje osudy už ked’ sa tvoria... "Denikové zápisky Moje deti E. M. Šoltésové a Dostojevského Denik spisovatele. In: GUNIŠOVÁ, Eliška - 
S. Šmatlák aj.). Podle Jána K. Garaje se jedná o „vrcholné dielo, jedinečnév našej literatúre, ba ojedinelé $i$ v svetovej literatúre vôbec“. ${ }^{16}$ Andrej Mráz charakterizuje zápisky jako „knihu vel'kých materinských radosti a múk, knihu mocnej ženskej vôle i hrdinského postoja $k$ životu“. ${ }^{17}$ Podle Stanislava Šmatláka „patria Moje deti vo svojom žánri k trvalým hodnotám slovenskej literatúry“. ${ }^{18}$ Myslíme si, že i kdyby Šoltésová už nic jiného nenapsala, tyto deníkové zápisky by jí svou jedinečností přinesly zaručený úspěch a literární renomé. Jsou koncipovány do dvou částí. V první části nacházíme zápisky, které se vztahují k jednomu dni, ale i souhrnná pozorování z celého měsíce, přičemž autorka sama přiznává, jak málo času jí na tyto zápisky zůstává. ${ }^{19}$ Již v Úvodu se Šoltésová vyjádř̌ila, že druhá část zápisků má jiný charakter než ta první. Zlom představuje část o smrti Elenky, která je mnohem subjektivnější a mnohem více v ní poznáváme autorku samotnou. Je zajímavé, že ve slovenské Hviezdoslavově knižnici svého času vyšel pouze první díl deníkových zápisků, vydání jejich pokračování však bylo ve své době odsouváno. Druhý díl zápisků byl doceněn až později. Zápisky Moje deti vznikaly v průběhu 28 let. První zápis autorka-matka napsala 28. 9. 1879, její dcerce Elence byly tehdy tři roky, synku Ivanovi jenom sedm měsíců. Ke genezi svých prvních zápisků se autorka vyjadřuje v memoárech Sedemdesiat rokov života. Uvádí, jak si unavená po práci zapisovala první postřehy o rozvíjejících se charakterech dětí: „[...] obyčajne večer, ked’ deti pospali a muž odišiel do kasina, zaznačovala som si do zošitov denné príbehy s detmi, až mi nejeden raz vypadlo pero z ruky od únavy a ospanlivosti." ${ }^{20}$ Poslední zápisek pochází z prosince roku 1917, když autorka z celé své rodiny zůstala sama.

Šoltésová své deníkové zápisky o dětech publikovala, vydání zápisků však zpočátku jejím cílem nebylo. Jak autorka uvádí v memoárech, zápisky chtěla původně uchovat jako památku pro děti, aby si je s odstupem času samy přečetly. Po smrti dětí jí zůstaly alespoň zápisky. ${ }^{21}$ Část o nemoci a smrti Elenky vyšla pod názvem Umierajúce diet’a v almanachu Živena v roce 1885. Zápisky o synovi Šoltésová uveřejňovala v Živeně pod názvem Môj syn. Na základě kritických ohlasư ${ }^{22}$ na části o nemoci Elenky si autorka vyčítala, že zápisky přináší čtenářum místo radosti a zábavy smutek: „Nad ,Mojim synom ‘ plakalo iste všetko

PAUČOVÁ, Lenka (eds.): Slovanský literární svět: kontexty a konfrontace I. Brno: Masarykova univerzita, 2015, s. 111-120.

16 GARAJ, Ján: Elena Maróthy Šoltésová. Turčiansky Sv. Martin: Ústredie Živeny, spolku slov. žien, 1939 , s. 26.

17 MRÁZ, Andrej: Dejiny slovenskej literatúry. Bratislava: Slovenská akadémia vied a umení, 1948, s. 229-230.

18 ŠMATLÁK, Stanislav: Dejiny slovenskej literatúry II. Bratislava: Literárne informačné centrum, 2001, s. 212.

19 Starost o děti a obchod, který autorka společně s manželem Ludovítem Šoltésem vlastnila, jí zabíraly většinu času (MARÓTHY-ŠOLTÉSOVÁ, Elena: Výber I. Bratislava: Tatran, 1978, s. 512).

20 Tamtéž, s. 512.

21 Tamtéž.

22 K uvedeným částem se kriticky vyjádřil S. Hurban Vajanský, přičemž jim vytýkal především absenci uměleckých výrazových prostředků v zobrazení bolesti a smutku: „Umierajúce diet'a od Eleny Šoltésovej je verný obraz samoprežitých bôlov. Živost' a bezprostrednost' citu bije až príliš do oči - a nie je zmiernená umeleckým prepracovaním. Naviest' na dušu až takmer fyzický bôl' nie je úlohou umenia. I s bôl'om musi umelec sporit', - no že nespori s ním matka, je pochopitelné. [...] No estetické dielo musí i oblažit', potešit' a povzniest'. Smrt' sama nemá ani oblaženia, ani potech, ani povznesenia." (HURBAN VAJANSKÝ, Svetozár: Literatúra a život. Bratislava: Tatran, 1990, s. 99) 
moje čitatel'stvo, a bude plakat' ešte i pri budúcom čísle. Dost’ ma to bolí že ich tak horko zabávam - ale bolo nám to iste predurčené: mne prežit’ a im prečitat. “23 Ve srovnání se Šoltésovou Lucie Nachtigallová své deníkové záznamy psala se záměrem publikovat, i když nejdř́ve před menším publikem na sociální síti. Ke knižnému vydání statusů publikovaných na sociální síti došlo až s odstupem času. V souvislosti s Deniky fejsbukové matky tedy můžeme mluvit o stylizaci, tj. snaze autorky ukázat se před čtenářským publikem v příznivějším světle.

Dílo E. M. Šoltésové Moje deti vnímáme z pohledu literárního žánru jako deník, autorka jej tak i sama nazývá. Můžeme však na něj také nahlížet jako na memoáry nebo kroniku. U Šoltésové tyto tři žánry jako by koexistují, jsou prostoupeny tak, že jeden se nachází na pozadí druhého. Žánr deníku vidíme jako soubor datovaných zápisků autorky-matky o dětech, vznikající periodicky v delším časovém období. Prostřednictvím memoárů autorka zachycuje události s časovým odstupem, přičemž se do popředí více dostává reflexe a hodnoticí aspekt. Ke kronice nás odkazuje již podtitul díla - Dva životy od kolísky po hrob. Autorku bychom v této souvislosti mohli nazvat kronikářkou rodinných událostí, protože v díle vystupuje jako omniscientní vypravěč. ${ }^{24}$ První část díla Moje deti je tvořena čtyřmi menšími celky (slov. Drobné obrázky z matkinho dennika, Svetlá a tiene, Väčšie deti, vä̌čsia starost'..., Prečo? Prečo?), jež se vyznačují dominancí výjevů z rodinného života sepsaných v deníkových záznamech. Žánr deníku se prolíná s memoáry, kroniku pozorujeme v pozadí. Dominantou druhé části díla, která obsahuje pět menších celků (slov. Jedinák, Gymnazista, Dospelý, Pri cieli, Dozvuky), se stávají memoáry, v pozadí zůstávají kronika a deník. Kronika vytváří v obou částech žánrové podloží (termín I. Pospíšila) ${ }^{25}$, můžeme však o ní uvažovat jen v obecné rovině, případně ještě jako o rodinné kronice, protože dílo nemá atributy např́íklad románové kroniky ${ }^{26}$. Ve srovnání s románovou kronikou v deníkových zápiscích E. M. Šoltésové můžeme pozorovat shodné prvky v povaze incipitu a explicitu, juxtapoziční zobrazení, příběhovost nebo dominantní syžetovou linii, na druhé straně v nich absentují další typy syžetových linií (formativní a katenální,

23 ROSENBAUM, Karol - KUSÝ, Ivan (eds.): Korešpondencia Timravy a Šoltésovej. Bratislava: Slovenská akadémia vied a umení, 1952, s. 55.

24 PAUČOVÁ, Lenka: „Knihy majú svoje osudy už ked’ sa tvoria... “ Deníkové zápisky Moje deti E. M. Šoltésové a Dostojevského Deník spisovatele. In: GUNIŠOVÁ, Eliška - PAUČOVÁ, Lenka (eds.): Slovanský literární svět: kontexty a konfrontace I. Brno: Masarykova univerzita, 2015, s. 116-117.

25 Tento termín používá Ivo Pospíšil v monografii Labyrint kroniky (1986) a Literárni genologie (2014). Viz POSPÍŠIL, Ivo: Labyrint kroniky. Pokus o teoretické vymezení žánru. Brno: Blok, 1986, s. 78, také POSPÍŠIL, Ivo: Literárni genologie. Brno: Masarykova univerzita, 2014, s. 28 a 95. Termín žánrové podloží najdeme také v pracích Ludvíka Štěpána, viz například jeho stat Žánrové podloži malých literárních forem S. J. Lece. (ŠTĚPÁN, Ludvík: Žánrové podloži malých literárních forem S. J. Lece. Opera slavica, 2000, č. 1, s. 22-30). V souvislosti s kronikovým půdorysem v žánru románové kroniky 19. století nebo později v dílech patřících do 20. století Pospíšil používá termín tzv. kronikové podloží. (POSPÍŠIL, Ivo: Labyrint kroniky. Pokus o teoretické vymezení žánru. Brno: Blok, 1986, s. 110-116)

26 Atributům románové kroniky se podrobněji věnuje POSPÍŠIL, Ivo: Labyrint kroniky. Pokus o teoretické vymezeni žánru. Brno: Blok, 1986, s. 20-35. 
termíny I. Pospíšila), ale také odbornost. ${ }^{27} \mathrm{~V}$ souvislosti s uvedenou literárněvědnou terminologií odkazujeme na statě Iva Pospíšila. ${ }^{28}$

Deníkové zápisky E. M. Šoltésové představují syntézu momentů, drobných obrázků ze života, miniaturních črt, konfesí a reflexí o výchově, životě, smrti i víre, můžeme je proto označit jako polymorfní. V první části převažuje radost, rodinné štěstí, sentiment; smrtí Elenky se tyto emoce vytrácí a nahrazuje je smutek, pošmournost, nostalgie ve druhé části. To se částečně projevuje i v žánrech: v první části najdeme především miniaturní črty, ve kterých autorka-matka sděluje pokroky dětí, přríhody s nimi. Zápisky této části zároveň představují i jistou konfesi, autorka se v nich přiznává, že předtím neměla vztah k dětem, ale všechno se pak změnilo a s vlastními dětmi přišla i láska k nim. Děti daly jejímu životu úplně nový rozměr, pocit štěstí, který člověku nic jiného nemůže vynahradit. Ve druhé části se také objevují črty a příběhy, převažují však reflexe o výchově Ivana, po jeho smrti reflexe o víře. ${ }^{29}$ Ve srovnání deníkových zápisků autorek pozorujeme žánrový posun od žánrové syntézy (Šoltésová) k jednoduchosti a nenáročnosti (Nachtigallová), žánrový posun je také patrný v důrazu na čtenářsky atraktivní př́běhost a vizuální prvek (Nachtigallová). Šoltésová ve svých deníkových zápiscích popisuje každodenní radosti i starosti, všímá si pokroků, rozvíjejících se úplně odlišných charakterů dětí. ${ }^{30}$ Plynutím času autorka sama poznává, jak „'tažká vec je deti vychovávat" ${ }^{31}$ Při pozorování dětí vyjadřuje své názory na výchovu. Zdůrazňuje, že každé dítě je jiné, rodič by měl podporovat jeho dobré vlastnosti. Čím jsou děti starší, stále více se projevují jejich chyby; autorku-matku znepokojuje paličatost Elenky, přílišná přejícnost a prudší povaha Ivana. Uvědomuje si, že výchova bez trestu není možná, nejdůležitější je však láska rodičů: „A už najbožskejšieho pôvodu musí byt’ najmä láska rodičovská, ktorá obdivuhodným, temer zázračným spôsobom zaujme srdce nielen dobrého, ale i zlého človeka, ked’ sa stane rodičom. Ona je tá dobrotivá, obetavá, sebazapierajúca, nikdy zlého neobmýšlajúca láska, ktorá všetkému sa úfa, všetko trpezlivo znáša, všetko odpúšta." "32

V souvislosti s osobností autorky deník vnímáme nejdříve jako jejího důvěrníka, později pro ni představuje jistou formu terapie. Deníku se autorka svěřuje i se svými obavami z budoucnosti, jestli se jí podaří vychovat z dětí dobré lidi, ale také s obavami o život dětí. Pokaždé, když jsou děti nemocné, bojí se o jejich život, v, aby co nejdříve vyrostly z nebezpečného věku, ve kterém jim hrozí nemoci, smrt. Anticipace ztráty se

27 PAUČOVÁ, Lenka: „Knihy majú svoje osudy už ked’ sa tvoria... “ Denikové zápisky Moje deti E. M. Šoltésové a Dostojevského Denik spisovatele. In: GUNIŠOVÁ, Eliška - PAUČOVÁ, Lenka (eds.): Slovanský literární svět: kontexty a konfrontace I. Brno: Masarykova univerzita, 2015, s. 116-117.

28 Viz POSPÍŠIL, Ivo: Problema struktury, funkcii i ispol'zovanija literaturovedčeskich terminov: po sledam sobstvennych popytok. Mirgorod, 2016, č. 2, s. 26-31; POSPÍŠIL, Ivo: Labyrinty literárněvědné terminologie. Philologia, 2018, č. 2, s. 7-20.

29 PAUČOVÁ, Lenka: „Knihy majú svoje osudy už ked’ sa tvoria... “ Denikové zápisky Moje deti E. M. Šoltésové a Dostojevského Denik spisovatele. In: GUNIŠOVÁ, Eliška - PAUČOVÁ, Lenka (eds.): Slovanský literární svět: kontexty a konfrontace I. Brno: Masarykova univerzita, 2015, s. 117.

30 „Vôbec vo všetkom sú celkom rozdielnej povahy moje dve deti. "MARÓTHY-ŠOLTÉSOVÁ, Elena: Moje deti. Dva životy od kolisky po hrob. Zápisky a rozpravy. Bratislava: Tatran, 1968, s. 43.

31 Tamtéž, s. 78.

32 Tamtéž, s. 43. 
v díle opakuje vícekrát, například když je Elenka opět nemocná, autorka uvádí: „[...] ja sa nemôžem zbavit’ zlého tušenia. “33 V memoárech se Šoltésová přiznává, že si nikdy nedovedla představit své děti v dospělém věku. Po smrti Elenky a Ivana autorčiny úvahy o výchově vystřídaly reflexe o smyslu života a mateřské lásce. Se ztrátou dětí se autorka nakonec smiřuje a sílu nachází ve víře ${ }^{34}$. V dané souvislosti lze uvést, že možnost vyjádřit prožitou bolest prostřednictvím deníkových zápisků poukazuje na terapeutickou funkci zápisků. Ve srovnání s Šoltésovou u Nachtigallové pozorujeme větší důraz na okamžik, jenž je v Denicich fejsbukové matky akcentován vizuálním prvkem. Přiloženou fotografii najdeme u většiny statusů, v díle nabývají kromě akcentace okamžiku i dalších funkcí, dotvářejí pointu, nebo v sobě nesou prvek humoru. U Šoltésové naopak dominuje popis reality.

Pro současné slovanské literatury je příznačný vznik autobiografických žánrů (memoáry, deníky, eseje aj.), nabízí se také nové možnosti zveřejnění literárních děl ve virtuálním prostoru (např. na sociálních sítích). V př́íspěvku byla naše pozornost soustředěna na dva deníky, jež jsou věnovány dětem: Denikům fejsbukové matky Lucie Nachtigallové vznikajícím v současné české literatuře a deníkovým zápiskům Moje deti slovenské spisovatelky Eleny Maróthy-Šoltésové, které patří k nejhodnotnějším dílům, jaké slovenská literatura minulého století přinesla. Srovnáním současné a minulé podoby žánru deníku o dětech jsme poukázali na žánrový posun. Deníkové zápisky autorek se na první pohled vzájemně liší již délkou, Nachtigallová své zápisky formuluje jako krátké zprávy vztahující se k určité situaci, Šoltésová především jako souhrnná pozorování z celého dne. U Nachtigallové má navíc důležité místo vizuální prvek v podobě fotografie, jež je přiložena k většině zápisků - statusů na sociální síti. Žánrový charakter deníkových zápisků autorek je rovněž rozdílný. U Nachtigallové pozorujeme dominanci juxtapozičnosti a př́iběhovosti podtržené čtenářsky atraktivní grafickou úpravou. Zápisky Šoltésové směřují od př́íběhovosti k reminiscentnosti a úvahám filozofické povahy. Ve srovnání s Nachtigallovou jsou její zápisky navíc žánrově bohatší: pozorujeme v nich prolínání žánru deníku a memoárů, přičemž v pozadí spatřujeme kroniku. U Nachtigallové jsme vymezili tři okruhy stěžejních témat (1. téma dětí, 2. témata spjatá s ostatními členy rodiny, 3. objektivní realita), přičemž konstatujeme, že charakter zápisků (krátkost, výstižnost) se projevil v tematické heterogenitě celého textu. Zajímavostí je, že o svých pocitech nebo vztahu k dětem se Lucie Nachtigallová explicitněji nevyjadřuje, v textu nalezneme pouze několik drobných poznámek.

Obě autorky zapůsobily na čtenáře a čtenářky ve své době, Elena Maróthy-Šoltésová prostřednictvím časopisu Živena a Lucie Nachtigallová díky sociální síti. Jestli budou deníkové zápisky Lucie Nachtigallové v budoucnu patřit k hodnotným dílům české literatury, nebo se svojí dobou zaniknou, ukáže čas.

33 Tamtéž, s. 382.

34 „Tu l'udská láska pochopila lásku božskú - a pošla z toho nezaniknutel'ná viera. “ Tamtéž, s. 386. 


\section{Literatura}

BOČKOVÁ, Hana: K problematice deniku jako literárniho žánru. Sborník prací Filozofické fakulty brněnské univerzity. 1989-1990. D, řada literárněvědná. 1989-1990, roč. 38-39, č. D36-37, s. 37-45. BURSOV, Boris: Dostojevskij a jeho svět. Praha: Odeon, 1978.

GARAJ, Ján: Elena Maróthy Šoltésová. Turčiansky Sv. Martin: Ústredie Živeny, spolku slov. žien, 1939.

HURBAN VAJANSKÝ, Svetozár: Literatúra a život. Bratislava: Tatran, 1990.

MARÓTHY-ŠOLTÉSOVÁ, Elena: Moje deti. Dva životy od kolísky po hrob. Zápisky a rozpravy. Bratislava: Tatran, 1968.

MARÓTHY-ŠOLTÉSOVÁ, Elena: Výber I. Bratislava: Tatran, 1978.

MAZÁK, Pavol et al.: Dejiny slovenskej literatúry II. 2. vyd. Bratislava: Slovenské pedagogické nakladatel'stvo, 1988.

MRÁZ, Andrej: Dejiny slovenskej literatúry. Bratislava: Slovenská akadémia vied a umení, 1948.

NACHTIGALLOVÁ, Lucie: Denik fejsbukové matky. Praha: Dobrovský s.r.o., 2016.

NACHTIGAllOVÁ, Lucie: Deník fejsbukové matky pokračuje. Praha: Dobrovský s.r.o., 2017.

NACHTIGALLOVÁ, Lucie: Deník fejsbukové matky (ne)konči. Praha: Dobrovský s.r.o., 2018.

ODEHNALOVÁ, Lenka: Dostojevského Denik spisovatele v kontextech a konfrontacích. Žánry - témata motivy - recepce. [Disertační práce]. Brno: Masarykova univerzita, 2021.

PAUČOVÁ, Lenka: „Knihy majú svoje osudy už ked’ sa tvoria... “Denikové zápisky Moje děti E. M. Šoltésové a Dostojevského Denik spisovatele. In: GUNIŠOVÁ, Eliška - PAUČOVÁ, Lenka (eds.): Slovanský literární svět: kontexty a konfrontace I. Brno: Masarykova univerzita, 2015, s. 111-120.

POSPÍŠIL, Ivo: Labyrint kroniky. Pokus o teoretické vymezení žánru. Brno: Blok, 1986.

POSPÍŠIL, Ivo: Labyrinty literárněvědné terminologie. Philologia, 2018, č. 2, s. 7-20.

POSPÍŠIL, Ivo: Literárni genologie. Brno: Masarykova univerzita, 2014.

POSPÍŠIL, Ivo: Problema struktury, funkcii $i$ ispol'zovanija literaturovedčeskich terminov: po sledam sobstvennych popytok. Mirgorod, 2016, č. 2, s. 26-31.

POSPÍŠILOVÁ, Marie: Facebooková (ne)závislost. Praha: Univerzita Karlova, 2016.

ŠMATLÁK, Stanislav: Dejiny slovenskej literatúry II. Bratislava: Literárne informačné centrum, 2001.

ROSENBAUM, Karol - KUSÝ, Ivan (eds.): Korešpondencia Timravy a Šoltésovej. Bratislava: Slovenská akadémia vied a umení, 1952.

ŠTĚPÁN, Ludvík: Žánrové podloži malých literárních forem S. J. Lece. Opera slavica, 2000, č. 1, s. 22-30.

\section{PaedDr. Lenka Odehnalová, Ph.D.}

Centrum jazykového vzdělávání, Univerzita obrany v Brně

Šumavská 4, 60200 Brno, Česká republika

lenka.odehnalova@unob.cz / 440234@mail.muni.cz

Pedagogická fakulta, Univerzita Hradec Králové

Rokitanského 62, 50003 Hradec Králové

Toto dílo Ize užít v souladu s licenčními podmínkami Creative Commons BY-SA 4.0 International (https://creativecommons.org/licenses/by-sa/4.0/legalcode). Uvedené se nevztahuje na díla či prvky (např. obrazovou či fotografickou dokumentaci), které jsou v díle užity na základě smluvní licence nebo výjimky či omezeni príslušných práv. 
